\title{
The Significance of Promoting Teacher Reflection: A Review Article
}

La importancia de promover la reflexión del profesor: artículo de revisión

A importância de promover a reflexão docente: artigo de revisão

Mahnaz MOAYERI

Tonekabon Branch, Islamic Azad University, Iran.

maah.moayeri@gmail.com

orcid.org/0000-0003-055I-9656

Ramin RAHIMIY

Tonekabon Branch, Islamic Azad University, Iran. drraminrahimy@toniau.ac.ir orcid.org/0000-0002-0859-7812 
ABSTRACT. The present review article is intended to bring the significant issue of teachers' reflective practice into the limelight by overviewing how this concept evolved through time and what it promises for successful teaching. The concept of teacher reflection, defined as teachers' beliefs about their teaching practice, has been subjected to a number of criticisms regarding its instrumental nature, disregard of social justice, and a vague reinforcement of the existing ideologies instead of challenging beliefs. These critiques have been discussed in this article, and possible ways to overcome the challenges are highlighted. Furthermore, pieces of evidence from a number of previous research studies are reviewed, which highlight how practicing reflection enables teachers to become aware of both their individual development and the different dimensions of the education program. It is further discussed that teacher reflection can benefit from different research perspective attempting to solve the ambiguities blurring its significance.

Keywords (Source: Unesco Thesaurus): Criticism; second language instruction; foreing languages; English as a foreign language; knowledge; teacher beliefs; teacher attitudes; teacher reflection.

RESUMEN. El presente artículo de revisión tiene como objetivo traer a un primer plano el importante tema de la práctica reflexiva de los docentes mediante un análisis de la evolución de este concepto a través del tiempo y lo que promete para el éxito en la enseñanza. El concepto de reflexión docente, definido como la opinión de los profesores sobre su práctica docente, ha sido objeto de una serie de críticas con respecto a su naturaleza instrumental, su indiferencia hacia la justicia social y un vago refuerzo de las ideologías existentes en vez de creencias desafiantes. En este artículo se discuten estas críticas y se hace hincapié en las posibles formas de superar los desafíos. Adicionalmente, se revisan las pruebas de una serie de estudios de investigación anteriores que destacan cómo la práctica de la reflexión les permite a los maestros tomar conciencia de su desarrollo individual y de las diferentes dimensiones del programa educativo. Se discute, además, que la reflexión docente puede beneficiarse de diferentes perspectivas de investigación que buscan resolver las ambigüedades que confunden su significación.

Palabras Clave (Fuente: tesauro de la Unesco): crítica; enseñanza de una segunda lengua; lengua extranjera; inglés como segunda lengua; conocimiento; creencias del profesor; actitud docente; reflexión del profesor.

RESUMO. O objetivo deste artigo de revisão é trazer à tona o importante tópico da prática reflexiva dos professores através de uma análise da evolução deste conceito ao longo do tempo e o que promete para o sucesso no ensino. O conceito de reflexão docente, definido como a opinião dos professores sobre sua prática docente, tem sido alvo de uma série de críticas sobre sua natureza instrumental,sua indiferença à justiça social e um vago reforço das ideologias existentes, em vez de crenças desafiadoras. Este artigo discute essas críticas e enfatiza os possíveis caminhos para superar os desafios. Além disso, revisam-se as evidências de uma série de pesquisas anteriores que analisam como a prática de reflexão permite que os professores se conscientizem de seu desenvolvimento individual e das diferentes dimensões do programa educacional. Discute-se, também, que a reflexão docente pode se beneficiar de diferentes perspectivas de pesquisa que buscam resolver as ambiguidades que confundem sua significação.

Palavras-chave (Fonte: tesauro da Unesco): crítica; ensino de segunda língua; língua estrangeira; Inglês como segunda língua; conhecimento; crenças do professor; atitude de ensino; reflexão do professor. 


\section{Introduction}

Since the 1980s, with the growth of second-language acquisition methods and the embracement of cognitive psychology, scholars in the field of both mainstream education and language teaching are inclined towards presuming teaching as a cognitive activity, with teachers having their own beliefs regarding the second language (L2) and English as a Foreign Language (EFL) instruction (Borg, 2003; Ellis, 2012; Freeman \& Richards, 1996). Considered as participants that are dynamically involved in the process of decision-making in classroom teaching, teachers play an indispensable role in language teaching (Sadeghi \& Khezrlou, 2016). In order to gain better insights regarding the process of language teaching, it is crucial to investigate how language teachers' reflections on their cognitions, their thinking, beliefs, and assumptions can be related to their classroom practices. As a result, research on language teaching has switched its attention from examining teachers' pedagogical activities to exploring their reflection on their teaching (Baker, 2014). This is particularly significant in EFL contexts where learners have limited exposure to the target language outside of the classroom and thereby teachers' choice of teaching methods and the classroom activities are generally influenced by the teachers' reflective practice in their teaching. Hence, in order to evaluate teachers' openness to new and different language teaching approaches and instructional practices, it is essential to shed light on their reflective practice.

In the present review article, the concept of teacher reflection is delineated and its essence regarding the teachers' understanding of their own teaching practices is highlighted. The purpose is to explore the evolution and developments in reflective practice over the past few years, from the 1990s to recent years, through an analysis of relevant literature concerning reflection and teacher development. We will outline the points that have emerged from recent literature, as well as a brief argument of the effect these developmental patterns in thinking might have about approaches to reflective practice in teacher development. The review of previous studies conducted in this area is expected to form our understanding of how teachers' reflective practice empowers or possibly hinders their actual teaching. Finally, there are implications for teachers and teacher educators, together with sugges- 
tions for further research that open up new horizons for both teaching and research purposes.

\section{Why Study Teachers' Reflective Practice?}

Reflective practice, according to Cook (2013), is related to

the experience of being a teacher, initiation into the teaching community, action research, personal development, teacher cognition, and beliefs-all of which are to be understood on the ground in context, by teachers themselves rather than by academics (like me), and within the practice of teaching rather than by withdrawing to gain perspective. (p. 14)

In order to perform reflection, teachers need to systematically gather information (data) with respect to their classroom practices, and then appraise if there are any conflicts between their beliefs and practices (Farrell, 2007). Getting involved in such evidence-based reflective practice empowers teachers to express to themselves (and others) what they do, how they do it, why they do it, and, lastly, how their teaching influences learners' achievement. The results of dealing with such data-driven reflective practice might imply a corroboration of present practices or the necessity of employing some modifications to current practices, since they may not reflect a teacher's specific beliefs (Farrell \& Ives, 2015). Subsequently, any shifts in a teacher's practices would be the outcome of sensible evidence instead of relying on impulses or routine.

Reflective practice, hence, equips teachers with a vision to recognize the impact of their beliefs on the pedagogical decisions they make while teaching. According to Borg (2003), "teachers are active, thinking decision-makers who make instructional choices by drawing on complex practically-oriented, personalized, and context-sensitive networks of knowledge, thoughts, and beliefs" (p. 81). However, some language teachers are not aware of their beliefs or the degree to which their beliefs are reflected in their classroom practices (Farrell, 2007). This is, in fact, considered a problem in the examination of teachers' reflection, since they are hidden to the teacher and they so need to be 
"brought to the level of awareness by being articulated in some way" (Farrell \& Bennis, 2013, p. 174). When teachers are offered an opportunity to express their beliefs about teaching and learning, they promptly figure out that their beliefs are not simple. As a result, if teachers are asked to cogitate consciously about their teaching practice, they could learn both their tacit beliefs and the significance of comparing their own beliefs with their practices by means of classroom observations, discussion, and reflection (Farrell, 2007). Farrell and Bennis (2013), for instance, found in their case study that, prior to the study, the two EFL teachers (i.e., one experienced and one a novice) were not conscious of their instructional beliefs until they were asked about them during interviews. Farrell and Bennis (2013) noted multiple occasions of hesitation and time spent on thinking about and articulating points while expressing beliefs. Senior (2006) has noted that a large number of teachers "do not have the inclination to sit down and reflect on the reasons that underlie their classroom decision making" (p. 247). Raising essential awareness is significant, as Knezedivc (2001) has illuminated, because it is the first stage of a process of declining the disagreement between what teachers do and what they think they do. Consequently, studying teachers' reflective practices allows us to make sense of their teaching processes and their justifications of the decisions that they make in their actual classroom teaching. Teachers' reflections mirror their practices, class planning and decision-making. In turn, teachers' classroom practices stimulate and reinforce their beliefs; in other words, the relationship is mutual (Richards, 2008).

The notion of reflective practice has been argued to be closely related to teacher education and research. Schon's (1983) model of the epistemology of practice is a well-recognized account of teacher education and research. The author distinguishes between reflection-in-action and reflection-on-action. Whereas the former acknowledges the implicit nature of thinking that comes with doing something and that leads to learning, the latter refers to the teachers' thoughtful consideration and retrospective investigation of their instruction in order to obtain knowledge from experience. It is reflection-on-teaching that can lead to teachers' conduction of exploratory practice or action research about their activities in the classroom. Hargreaves (1996) has advocated the remarkable engagement of teachers as practitioners with the 
research process, in order to set up a reliable, evidence-base of what "teachers do in classrooms" (p. 7). Action research of this type could bring about a suitable and legitimate means by which individuals and groups of teachers may indirectly gain support and encouragement for change, while being inadvertently directed into taking on responsibility for solving problems and divergence (Leitch \& Day, 2000). Therefore, while still performing a substantial role in promoting reflective practice, there are obviously numerous types of action research. Action research will, according to specific objectives, have different types of advantages; it reflects the types of teaching practices motivated or demotivated by policy makers, and, more importantly, it illuminates the meaning of professionalism in terms of teachers' expertise.

The notion of teacher reflection has been both welcomed by educational research (e.g., Artzt \& Armour-Thomas, 2002; Margolis, 2002; Moore, 2002) and criticized (McNay, 1999; Smyth, 1992; Zeichner, 1996). One criticism is that teachers' reflective practice could not support their role in the classroom. Zeichner (1996), for instance, proposes four issues that clarify the reasons that teachers' reflective practices weakened the intended goals for teachers: the preference of university research over teacher action research, a focus on teaching procedures and classroom management, a lack of attention to the social and institutional teaching environment, and personal reflection in place of group sharing. Another criticism leveled at reflective practice is the assumption that reflective practice functions as a reinforcement of the existing cognitions instead of challenging beliefs. In other words, reflective practice is deemed to be a simple exercise in terms of reapproving, justifying, or rationalizing pre-recognized opinions. Loughran (2002), for instance, postulates that justification can masquerade as reflection. Additionally, the findings of a study by Korthagen and Wubbles (1995) did not show a connection between reflectivity and a tendency towards innovative teaching.

Reflective practice has been subjected to another criticism: the extent to which it aims at presenting an instrumental analysis and disregarding issues related to social justice. Instrumental reflection is mainly intended to enable teachers to become successful in transmitting knowledge or increasing learners' test scores, and therefore it has been criticized for not advancing social reconstruction of injustice 
(Gomez, 1996). Gomez (1996) reported that reflective practice performs a complicated and controversial role in the training of teachers for cultural diversity. For example, learners might use reflective writing to strengthen their racist presumptions.

These doubts about the functionality of reflective practices can sometimes be sorted out. As an example, the conservative aspect of reflection can be overcome by integrating a social aspect to reflective practice, making reflection public and accessible to critique among friends and peers (Loughran, 2002). A further solution is introducing a spiritual and meaning-based aspect to teaching practice, attempting to present a fresh viewpoint (Khezrlou, 2012, 2018; Khezrlou, Ellis, \& Sadeghi, 2017; Mayes, 2001).

As a way of understanding the concept of reflection and weighing its drawbacks and strengths, it seems sensible to examine the concept in practice as documented by a plethora of works in this area. Below, we provide an overview of the studies that examine teacher reflective practice.

\section{Empirical Evidence}

Classroom experience leading to teachers' beliefs about language teaching usually relies on teachers' reflection on their own practices (Borg, 2003; Kagan, 1990; Woods, 1996). Teachers' teaching beliefs may be reinforced or modified by reflections on their use of the teaching methods, learners' responses, reflective journals, and peer review (Borg, 2003; Woods, 1996). A number of research attempts have investigated how reflective practice inspires teachers to change and update their classroom teaching after receiving several years' professional training or after teaching learners for many years. In the present study, a total number of 51 articles concerned with teacher reflection were selected. The articles were written by authors with a research background in teacher education and intentionally attempted to present particular ideas about reflection to improve teaching practice. Most of the selected articles discussed the ideas in a common language to teachers. The inclusion criteria for review of articles includes two aspects: a) whether 
the goal of the report was to make reflection better recognized and welcomed by teachers; and b) whether the reports were meant to provide a coherent proposal/experience regarding reflection to teachers. Some of the most prominent studies and their contributions to this area are overviewed in the following section.

Nespor (1987) revealed that teachers with frequent reflective practice would adopt methods that they perceived successful in their previous classroom teaching. In a case study, Moran (1996) found that a teacher in the United States modified her classroom teaching as a result of reflection on her learners' reactions to her teaching methods. Jamil and Hamre (2018) drew on observations of a real classroom to suggest that early childhood teachers' engagement in a continual reflection could significantly help them improve their reactions to classroom issues over time and could foster the teacher-child interaction in the classroom. Silveria, Beauregard, and Bull's (2017) study on the effect of an authentic assessment tool (processfolio) on pre-service teachers' reflection highlighted the success of processfolio in making pre-service teachers become personally aware of their development and to understand the different aspects of the music education program. However, teachers were a bit confused about the use of processfolio without adequate examples. Bell and Aldridge (2014) investigated how learners' feedback led to teachers' reflection and found that teachers employed the feedback as part of a formal action research approach consisting of entries in reflective journals, written reports, and participation in discussion forums. Additionally, and perhaps more importantly, the actual involvement in reflection created self-assurance to possess, state, utilize and further develop the teachers' theories (Hacker \& Barkhuizen, 2008). The reflective process itself seems to satisfy Freeman's articulation of the substantial purpose of education: "to understand experience" (Freeman, 2002, p. 11).

As is obvious from previous research, personal teacher reflection, together with the promotion of reflective practice and action research (see, for example, Brennan, Meyer, Munn-Giddings, Somekh, \& Walker, 2008) welcomed by teachers, has brought about the flourishing field of "self-study." Desiring to comprehend the problems that inundated teacher education (see Sykes, Bird,\& Kennedy, 2010 for a discussion of 
the dilemmas in teacher education), educators embrace and apply to their own work research practices that clarify their teaching, which in turn is advantageous for their students learning (Loughran, 2002). Reflection is, therefore, empirically found to be integral to teachers' learning, where learning is a coterie of cognition, not delivery of information (Freire, 1970). This is consistent with Bandura's (1997) concept of teachers' self-efficacy beliefs, which he believes are not the sole indicators of their actions, since teachers' actions are integrated into the social structure and their self-systems. In such systems, teachers contribute to what they become and perform by practicing self-reflection, self-regulation, self-influence, and self-images of future successes and failures (Bandura, 1997).And such self-reflection, self-regulation, self-influence and self-images, in turn, shape or reshape their beliefs about specific concepts/activities, such as behavioral belief, normative belief and control belief (Ajzen, 1991; Ellis, 2012).

\section{Implications}

From a practical point of view, it can be argued that this review presents the mainstay of reflective practice, which carries significant implications for teacher education (Brookfield, 2002). Firstly, teachers' determined and explicit reflection on their experiences, predictions, and individual development reflects their cultural awareness, instructional, interpersonal, and personal knowledge (Barkhuizen \& Feryok, 2006), and emotional awareness in past situations (Bandura, 1986; Oettingen, 1995; Sadeghi \& Khezrlou, 2014). Such reflection redevelops the importance of teachers' experiences both in interpersonal and intrapersonal contexts (Barkhuizen \& Feryok, 2006; Lantolf \& Pavlenko, 1995). Secondly, teachers' reflection on their teaching experiences, such as some "turning points," will not only augment the comprehension of their existing beliefs and practices but also cultivate their robust self-efficacy perceptions. The concept of teacher reflection calls for the need for educational researchers to explore their presumptions about the link between research and teacher education. The experience of narrating 
is valuable because it creates an opportunity for reflection on the hidden and the more easily remembered events of life. Future research could look into reflective practice from a narrative inquiry perspective, which invokes talking about experience allowing the narrator to make meaning of the experience; and reflection is undoubtedly central to this meaning-making dimension of story-telling. The narrative interview apparently creates an opportunity for teachers to reflect on their histories of coming to language teacher education, on significant or meaningful educational experiences, and on experiences in their instructional context. Furthermore, it would offer them the liberty to include or exclude details of those foci. On these counts of personal meaning-making of experiences and personal choice in disclosing details of certain topics, the narrative interview could be an ideal learning tool to include in a collaborative professional development program.

A number of things must be considered in order to achieve a more fruitful critical reflection process. First, it seems vital to provide teachers with more evidence-based or research-approved information on what works in reflective practice by presenting relevant journals or educational programs that might reinforce it. This could be achieved by employing procedures and methods, as well as validated or content-rich reports on reflective practices that work. Second, teachers themselves are encouraged to analyze class data on a constant basis and ask deep-seated queries about teaching effectiveness in the classroom. They can achieve this by conducting action research. The point is that the distinction between conducting a particular action research project and simply being a reflective teacher is that, in the former, teachers are directed towards putting all of their thoughts and beliefs together in such a way that new observations can be born (Zeichner \& Gore, 1995). Considering reflection as the engine of action research processes (Leitch \& Day, 2000), it boosts the learning possibilities for all those concerned. This is in line with the essence of teachers' being lifelong learners in the ever more arduous and complex worlds of classrooms and schools.

In summary, it is apparent that reflective practice is the evidence or embodiment of learning; what is learned and how that learning occurs with respect to the visible aspects of language teaching. Nev- 
ertheless, the details of an individual teacher's reflective experience are highly particular. Reflection is inevitably connected with extremely individualized interpretations of such notions as beliefs, identity, work history, and passion, all of them intensely rooted in a history unique to the individual teacher.

\section{Conclusion}

The goal of exploring language teacher reflections and classroom practices is not to find out the "best practices"; instead, the purpose is to note what it is, so that teachers can gain more confidence about what they believe about language teaching and learning so it can be reflected in their classroom practices. Professional growth stems from redeveloping the experiences and then reflecting on these experiences, enabling us to cultivate our own approaches to teaching (Basturkmen, 2012; Knezedivc, 2001). As Woods (1996) has warned, language teachers need to be on guard against any statement of "allegiance to beliefs consistent with what they perceive as the current teaching paradigm rather than consistent with their unmonitored beliefs and their behavior in class" (p. 71). Importantly, as Howard (2003) describes, reflection is a process related to action and it is an ongoing process predicated on consistent cogitation about one's activities and then their alteration, accordingly. For teacher educators involving pre-service teachers in reflective practice, it is vital to note that one never completely reaches the end regarding reflection. The very nature of teaching is dependent on revisiting curriculum, instruction, and evaluation. Teachers need to be mindful of the fact that even the most experienced teachers are susceptible to mistakes, slips in evaluation, or other types of missteps. Nevertheless, they are capable of reflecting on their weaknesses and improving their teaching accordingly. Reflection is a process of enhancing practice, rethinking philosophies, and becoming helpful teachers for today's ever-changing learner population. By carrying out reflective practice, teachers are able to construct and reconstruct their own beliefs and practices, allowing them to offer optimal learning conditions for their learners. 


\section{References}

Ajzen, I. (1991). The theory of planned behavior. Organizational Behavior and Human Decision Processes, 50, 179-211. DOI: https://doi. org/10.1016/0749-5978(91)90020-T

Artzt, A. F., \& Armour-Thomas, E. (2002). Becoming a reflective mathematics teacher: A guide for observations and self-assessment. Mahwah, NJ: Lawrence Erlbaum Associates.

Baker, A. A. (2014). Exploring teachers' knowledge of second language pronunciation techniques: Teacher cognitions, observed classroom practices, and student perceptions. TESOL Quarterly, 48(1), 136-163. DOI: https://doi.org/10.1002/tesq.99

Bandura, A. (1986). Social foundations of thought and action: A social cognitive theory. Englewood Cliffs, NJ: Prentice-Hall.

Bandura, A. (1997). Self-efficacy: The exercise of control. New York, NY: W.H. Freeman.

Barkhuizen, G., \& Feryok, A. (2006). Pre-service teachers' perceptions of a shortterm international experience program. Asia-Pacific Journal of Teacher Education, 34(1), 115-134. DOI: https://doi.org/10.1080/13598660500479904

Basturkmen, H. (2012). Review of research into the correspondence between language teachers' stated beliefs and practices. System, 40, 282-295. DOI: https://doi.org/10.1016/j.system.2012.05.001

Bell, L. M., \& Aldridge, J. M. (2014). Investigating the use of student perception data for teacher reflection and classroom improvement. Learning Environments Research, 17(3), 371-388. DOI: https://doi.org/10.1007/ s10984-014-9164-z

Borg, S. (2003). Teacher cognition in language teaching: A review of research on what language teachers think, know, believe and do. Language Teaching, 36(2), 81-109. DOI: https://doi.org/10.1017/ S0261444803001903

Brennan, M., Day, C., Meyer, J., Munn-Giddings, C., Somekh, B., \& Walker, M. (2008). Educational action research. London, UK: Routledge.

Brookfield, S. D. (2002). Using the lenses of critically reflective teaching in the community college classroom. Community College Faculty: Characteristics, Practices and Challenges, 118, 31-38. DOI: https://doi. org/10.1002/cc.61 
Cook, G. (2013). English language teacher education: Notes on the past and future. Linguaculure, 2, 9-22. DOI: https://doi.org/10.1515/lincu-2015-0011

Ellis, R. (2012). Language teaching research and language pedagogy. Oxford, UK: Wiley-Blackwell.

Farrell, T. S. C. (2007). Reflective language teaching: From research to practice. London, UK: Continuum.

Farrell, T. S. C., \& Bennis, K. (2013). Reflecting on ESL teacher beliefs and classroom practices: A case study. RELC, 44(2), 163-176. DOI: https:// doi.org/10.1177/0033688213488463

Farrell, T. S. C., \& Ives, J. (2015). Exploring teacher beliefs and classroom practices through reflective practice. Language Teaching Research, 19(5), 594-610. Doi: https://doi.org/10.1177/1362168814541722

Freeman, D. (2002). The hidden side of the work: Teacher knowledge and learning to teach. A perspective from North American educational research on teacher education in English language teaching. Language Teaching, 35, 1-13. Doi: https://doi.org/10.1017/S0261444801001720

Freeman, D., \& Richards, J. C. (1996). The "unstudied problem": Research on teacher learning in language teaching. In D. Freeman \& J. C. Richards (Eds.), Teacher learning in language teaching (pp. 351-378). Cambridge, UK: Cambridge University Press.

Freire, P. (1970). Pedagogy of the oppressed. New York, NY: Seabury Press.

Gomez, M. L. (1996). Prospective teachers' perspectives on teaching “Other People's Children". In K. Zeichner, S. Melnick, \& M. L. Gomez (Eds.), Currents of reform in preservice teacher education (pp. 109-132). New York, NY: Teachers College Press.

Hacker, P., \& Barkhuizen, G. (2008). Autonomous teachers, autonomous cognition: Developing personal theories through reflection in language teacher education. In T. Lamb, \& H. Reinders (Eds.), Learner and teacher autonomy: Concepts, realities and responses (pp. 161-1 83). Amsterdam, The Netherlands: John Benjamins.

Hargreaves, D. (1996). Teaching as a research-based profession: Possibilities and prospects. London, UK: Teacher Training Agency.

Howard, T. C. (2003). Culturally relevant pedagogy: Ingredients for critical teacher reflection. Theory into Practice, 42(3), 195-202. DOI: https:// doi.org/10.1207/s15430421tip4203_5

Jamil, F. M., \& Hamre, B. K. (2018). Teacher reflection in the context of an online professional development course: Applying principles of cog- 
nitive science to promote teacher learning. Action in Teacher Education, 40(2), 220-236. DOI: https://doi.org/10.1080/01626620.2018.1424051

Kagan, D. M. (1990). Ways of evaluating teacher cognition: Inferences concerning the goldilocks principle. Review of Educational Research, 60(3), 419-469. DOI: https://doi.org/10.3102/00346543060003419

Khezrlou, S. (2018). Form-focused instruction in CALL: What do learners think? RELC, 1-17. DOI: https://doi.org/10.1177/0033688217738820

Khezrlou, S. (2012). The relationship between cognitive and metacognitive strategies, age and level of education. The Reading Matrix, 12(1), 50-61. Retrieved from http://www.readingmatrix.com/articles/april_2012/ khezrlou.pdf

Khezrlou, S., Ellis, R., \& Sadeghi, K. (2017). Effects of computer-assisted glosses on EFL learners' vocabulary acquisition and reading comprehension in three learning conditions. System, 65, 104-116. DOI: https://doi.org/10.1016/j.system.2017.01.009

Knezedivc, B. (2001). Action research. IATEFL Teacher Development SIG Newsletter, 1, 10-12.

Korthagen, F. A., \& Wubbels, T. (1995). Characteristics of reflective practitioners: Towards an operationalization of the concept of reflection. Teachers and Teaching: Theory and Practice, 1(1), 51-72. DOI: https://doi. org/10.1080/1354060950010105

Lantolf, J. P., \& Pavlenko, A. (1995). Sociocultural theory and second language acquisition. Annual Review of Applied Linguistics, 15, 108-124. DOI: https://doi.org/10.1017/S0267190500002646

Leitch, R., \& Day, C. (2000). Action research and reflective practice: Towards a holistic view. Educational Action Research, 8(1), 179-193. DOI: https:// doi.org/10.1080/09650790000200108

Loughran, J. J. (2002). Effective reflective practice: In search of meaning in learning about teaching. Journal of Teacher Education, 53(1), 33-43. DOI: https://doi.org/10.1177/0022487102053001004

Margolis, J. (2002). Reforming reflection and action in English education. English Education, 34(3), 136-214.

Mayes, C. (2001). Deepening our reflectivity. The Teacher Educator, 36(4), 248264. DOI: https://doi.org/10.1080/08878730109555270

McNay, L. (1999). Gender habitus and the field: Pierre Bourdieu and the limits of reflexivity. Theory, Culture, and Society, 16(1), 95-117. DOI: https://doi.org/10.1177/026327699016001007 
Moore, K. B. (2002). Reflection for program improvement. Scholastic Early Childhood Today, 16(7), 12-13.

Moran, P. R. (1996). "I'm not typical”: Stories of becoming a Spanish teacher. In D. Freeman \& J. C. Richards (Eds.), Teacher learning in language teaching (pp. 125-153). Cambridge, UK: Cambridge University Press.

Nespor, J. (1987). The role of beliefs in the practice of teaching. Journal of Curriculum Studies, 19(4), 317-328. DOI: https://doi. org/10.1080/0022027870190403

Oettingen, G. (1995). Cross-cultural perspectives on self-efficacy. In A. Bandura (Ed.), Self-efficacy in changing societies (pp. 149-176). New York, NY: Cambridge University Press.

Richards, J. C. (2008). Second language teacher education today. RELC Journal, 39(2), 158-177. DOI: https://doi.org/10.1177/0033688208092182

Sadeghi, K., \& Khezrlou, S. (2014). Burnout among English language teachers in Iran: Do sociodemographic characteristics matter? Procedia- Social and Behavioural Sciences, 98, 1590-1598. DOI: https://doi. org/10.1016/j.sbspro.2014.03.582

Sadeghi, K., \& Khezrlou, S. (2016). The experience of burnout among English language teachers in Iran: Self and other determinants. Teacher Development, 20(5), 1-17. DOI: https://doi.org/10.1080/13664530.2016 .1185028

Schön, D. A. (1983). The reflective practitioner. New York, NY: Basic Books.

Senior, R. (2006). The experience of language teaching. New York, NY: Cambridge University Press.

Silveria, J. M., Beauregard, J., \& Bull, T. (2017). Development of the processfolio: Promoting preservice music teacher reflection through authentic assessment. Journal of Music Teacher Education, 27(1), 11-23. DOI: https://doi.org/10.1177/1057083717697632

Smyth, J. (1992). Teachers' work and the politics of reflection. American Educational Research Journal, 29(2), 267-300. DOI: https://doi. org/10.3102/00028312029002268

Sykes, G., Bird, T., \& Kennedy, M. (2010). Teacher education: Its problems and some prospects. Journal of Teacher Education, 61(5), 464-476. DOI: https://doi.org/10.1177/0022487110375804

Woods, D. (1996). Teacher cognition in language teaching: Beliefs, decision-making, and classroom practice. Cambridge, UK: Cambridge University Press. 
Zeichner, K. (1996). Introduction. In K. Zeichner, S. Melnick, \& M. L. Gomez (eds.), Currents of reform in preservice teacher education (pp. 1-8). New York, NY: Teachers College Press.

Zeichner, K. M., \& Gore, J. M. (1995). Using action research as a vehicle for student reflection. In S. Noffke \& R. B. Stevenson (Eds), Educational action research (pp. 121-138). New York, NY: Teachers College Press. 